\title{
Vergi Hukukunda Uzlaşma Kurumu ve Komisyonları
}

\author{
Sevil Şin* \\ Yalova Üniversitesi \\ Çınarcık Meslek Yüksekokulu \\ orcid.org/0000-0003-4454-9209
}

\begin{abstract}
$\ddot{O} z$
İdare-mükellef arasındaki anlaşmazlıkların çözümlenmesi noktasında uzlaşma kurumu hem yöntem, hem de zaman niteliği ile ön plana çıkmakta ve diğer uyuşmazlık çözüm yöntemlerinden ayrlmaktadır. Vergi hukukunda pek çok yönden önemli bir yere ve özelliklere sahip bir kurum olan uzlaşmanın en önemli özelliklerinden birisi uzlaşma komisyonlarına tanınmış olan takdir yetkisidir. Vergi hukukunda takdir yetkisi kanunilik ilkesi gereği istisnai bir yetkidir. Komisyonlarn uzlaşma sürecini yürütme sürecinde asli yetkileri bağlı yetki olup takdir yetkisi istisnaidir. İstisnai niteliğine rağmen uzlaşma komisyonlarına vergi hukukundaki (belki de) en geniş takdir yetkisi tanınmıştır. Uzlaşma komisyonları da bağlı yetki ve takdir yetkisi sınırları kapsamında uzlaşma kurumunun işletilmesini sağlarlar. Bu çalışmanın amacı uzlaşma kurumunun etkin bir şekilde işleyip işlemediğinin belirlenmesi, varsa aksayan yönlerinin tespit edilmesi suretiyle kurumun vergi hukukuna katkısının arttırılmasıdır. Bu amaçla konu ilgili yasal düzenlemelerin ışı̆̆ında, vergi yargısına dava konusu edilmiş vakalardan da yararlanarak teorik açıdan incelenmiştir. Yapılan inceleme sonucunda uzlaşma başvurusuna ilişkin yasal düzenlemenin gözden geçirilmesi (tarhiyat sonrası uzlaşma özelinde), kurumun hukuki statüsüne belirlilik kazandırlması (özellikle tutanakla tespit edilen hususlarla ilgili sonradan ortaya çıan ve düzeltilmesi gereken işlemler bakımından), uzlaşma komisyonlarına tanınan takdir yetkisinin sinırlarının belirlenmesi gerektiği sonucuna ulaşılmıştır.
\end{abstract}

Anahtar Kelimeler: Vergi, Vergi Hukuku, Uzlaşma Kurumu, Uzlaşma Komisyonları.

\section{Reconciliation Institution and Commissions in Tax Law}

\begin{abstract}
In the reconciliation for the solution disagreements between the administration and the taxpayer, the reconciliation institution has great importance on both method and time ant it diverges from the other dispute resolution methods. One of the most important features of the reconciliation institution which is important in the tax law in many aspects and has many important qualities is the discretionary power given to the reconciliation commissions. The discretionary power in tax law is an exclusive power due to the law. The fundamental power of the commissions in carrying out the reconciliation is a legal power, and the discretionary power is exceptional. In spite of its exceptional feature the reconciliation commissions are given (maybe) the widest power in tax law. The reconciliation commissions provide the functionality of the reconciliation organization within the limits of the legal power and discretionary power. The purpose of this study is to determine whether the settlement institution operates effectively and to enhance its contribution to the tax law by determining the deficiencies if any. For this purpose, in the light of the relevant legal regulations, the tax judgment has been examined from a theoretical point of view by taking advantage of cases that have been the subject of litigation. As a result of the investigation, it was concluded that the legislative regulations regarding the application for reconciliation should be reviewed (specific to reconciliation after assessment), the legal status of the institution (especially in respect of the transactions which should be established and corrected
\end{abstract}


after the issues determined by the minutes) should be determined and the limits of the discretionary commissions granted to the reconciliation commissions should be determined.

Keywords: Tax, Tax Law, Reconciliation Institution, Reconciliation Commissions.

\section{Giriş}

Yasal düzenlemelerinde kavramsal bir tanımı yapılmamış olan uzlaşma, birden çok kişinin aralarında mevcut ya da ileride çıkması muhtemel düşünce ve çıkar ayrılığını karşılıklı ödünler vererek gidermelerini veya bu konuda anlaşmalarını anlatan bir kavramdır (Kızılot, 2007:1288). Danıştay İçtihatları Birleştirme Kurulu (DİBK), bir kararında uzlaşmayı "vergi idaresi ile mükellefler ya da adlarına ceza kesilenler arasında, vergi kanunlarının uygulanması nedeniyle doğan uyuşmazlıkların; tarafların karşılıklı görüşmeleri yolu ile, daha başlangıçta ödenecek olan vergi ve ceza miktarı üzerinde mutabakat sağlanarak ortadan kaldırılması, yargısal yol ve usullerin uygulanmasına gerek bırakılmaksızın çözüme kavuşturulması" şeklinde tanımlamıştır ${ }^{1}$. Vergi Usul Kanunu (VUK) gerekçesinde uzlaşmanın amacı, vergi uyuşmazlıklarının süratle çözümü ve böylece mükelleflerin tereddütlerinin bir an önce giderilmesi suretiyle onların huzura kavuşmalarının sağlanması, mükellefle idare arasında vergi yönünden ortaya çıkan uyuşmazlıkların mümkün olan en kısa sürede çözüme bağlanması ${ }^{2}$ olarak ifade edilmiştir.

VUK, ek-1, ek-11 maddeleri ile Tarhiyat Sonrası Uzlaşma- Tarhiyat Öncesi Uzlaşma Yönetmelikleri ${ }^{3}$ ile bunlara ilişkin düzenlemelerin yer aldığ1 VUK Genel Tebliğleri uzlaşma kurumunun yasal zeminini oluşturmaktadır. Uzlaşma kurumunun vergi sistemimizde ilk düzenlenmesi tarhiyat sonrası uzlaşma ile olmuştur.1963 yılında 205 sayılı kanunla getirilen düzenleme ile uzlaşma vergilendirme sürecinin tarh aşaması ile tarh edilen vergi /ceza hakkında mümkün bulunmakta idi. 1985 yılında 3239 sayılı kanunla getirilen düzenleme ile uzlaşma kurumuna tarhiyat öncesi uzlaşma eklenmiş, böylelikle mükellef-idare arası uzlaşı zeminine tarhiyat öncesi dönem de dahil edilmiştir. Tarhiyat sonrası uzlaşma kurumu 205 Sayılı Kanunla ek madde-1 ile ek- 9.maddelerde yer alan düzenlemeler zaman içinde çeşitli değişikliklere uğramış nihayetinde ek- 2-5.maddelerin yürürlüğüne 4369 sayılı kanunla son verilmiştir. Tarhiyat öncesi uzlaşmanın düzenlendiği ek madde-11 ise kabulünden sonra muhtelif sayılı kanunlarla bazı değişikliklere tabi tutulmuştur. İl Özel İdareleri ile Belediyelere ait vergi, resim ve harçlar için Uzlaşma Yönetmeliği İçişleri Bakanlığınca düzenlenirken $^{4}$, gümrük vergileri 2011 yılında 4458 sayılı Gümrük Kanunu 244.maddenin verdiği yetkiye dayanılarak çıkarılan Uzlaşma Yönetmeliği ile uzlaşma kapsamına alınmıştır 5 .

\footnotetext{
${ }^{1}$ DİBK, E. 1986/2,K. 1986/2

2 VUK Gerekçesi, D.4.D. 1997/4651 E.,1998/4546 K.

3 3.2.1999 tarih 23600 Numaralı Resmi Gazete ile Tarhiyat Sonrası Uzlaşma Yönetmeliği ile 31.10.2011Tarih 28101 Numaralı Resmi Gazete ile Tarhiyat Öncesi Uzlaşma Yönetmeliği.

4 1.8.2003Tarih 25186 numaralı Resmi Gazete

${ }^{5}$ 27.8.2011Tarih 28038 Numaralı Resmi Gazete. Gümrük Vergileri ile bunlarla ilgili para cezalarıyla ilgili Uzlaşma bu Yönetmelik esasları çerçevesinde yürütülür.
} 
Etkin bir şekilde işleyip işlemediğinin tespit edilerek vergi hukukuna katkısının arttırılması amacıyla uzlaşma kurumu; kapsamı, uzlaşma komisyonları, tarafları, süreci, takdir yetkisi kullanımı, uzlaşma kurumunun değerlendirilmesi yasal düzenlemeler ve yargı kararları 1şı̆̆ında teorik çerçevede incelenmiştir. Bu inceleme sonucunda, başvuru şartları arasında (tarhiyat sonrası uzlaşma için) yer alan tarhiyatın hangi sebeple yapıldığının tespiti hususunun ayrı bir uyuşmazlığa neden olabilme potansiyeli olası uzlaşma zeminini ortadan kaldırdığı gibi yeni bir uyuşmazlık konusunun doğumuna da neden olabildiği, uzlaşma tutanağında düzeltilmesi gereken hususların tespiti (sonradan) durumunda bunun ne şekilde düzeltilebileceği hususunun belirsizliği, ayrıca, uzlaşma komisyonlarının takdir yetkisi sınırlarına yönelik bir belirleme yapılmamış olması üzerinde durulması gereken önemli unsurlar olarak karşımıza çıkmıştır. VUK, ek-1.maddedeki uzlaşma başvurusuna ilişkin yasal düzenlemenin gözden geçirilmesi, tutanakla tespit edilen hususlarla ilgili sonradan ortaya çıkn ve düzeltilmesi gereken işlemlerin niteliği ile uzlaşma komisyonlarına tanınan takdir yetkisinin sınırlarının belirlenmesi gerektiği sonucuna ulaşılmıştır.

\section{Uzlaşma Kapsamı}

Genel bütçeye giren vergi, resim, harçlar ile bunlara bağlı vergi ziyaı cezaları uzlaşma kapsamındadır. Bu vergi, resim, harç ve bunlara ait vergi ziyaı cezaları için başvurulabilecek uzlaşma tarhiyat öncesi ve tarhiyat sonrası uzlaşma olarak düzenlenmiştir. Tarhiyat öncesi uzlaşma konusuna, vergi incelemesi yapmaya yetkili olanlarca yapılan vergi incelemelerine dayanarak tarh edilecek ve Bakanlık vergi dairelerinin tarha yetkili oldukları bütün vergi, resim ve harçlar ile bunlara ilişkin olarak kesilecek vergi ziyaı cezası ${ }^{6}$ dahildir. Tarhiyat sonrası uzlaşma kapsamına ikmalen, resen veya idarece tarh olunan ve Bakanlık vergi dairelerinin tarha yetkili olduğu bütün vergi ${ }^{7}$, resim ve harçlar ile bunlara ilişkin olarak kesilecek vergi ziyaı cezaları girer. VUK ek-1 ve ek-11.maddelerinde yer alan yasal düzenlemede .. "ikmalen, resen veya idarece tarh edilen vergilerle bunlara ilişkin vergi ziyar cezalarının...(VUK ek-1)”, “...vergi incelemesine dayanılarak tarh edilecek vergilerle bunlara ilişkin kesilecek vergi ziyaı cezalarında...(VUK ek-11)" ifadelerinden komisyonların vergi aslı ve vergi ziyaı cezası bakımından uzlaşma yetkisine sahip oldukları anlaşılmaktadır. VUK, ek-11.madde “...vergi incelemesine dayanılarak tarh edilecek vergilerle..." ibaresinden tarhiyat öncesi uzlaşmanın vergi denetim sisteminde yer alan denetim mekanizmalarından sadece vergi inceleme aşamasını kapsadığı anlaşılmaktadır.

Vergi cezaları açısından VUK/ 359.maddede yazılı fiillerle vergi ziyaına sebebiyet verilmesi halinde tarh edilen vergi ve kesilen ceza, bu fiillere iştirak edenlere kesilen ceza uzlaşma kapsamı dışında tutulmuştur. Usulsüzlük ve özel usulsüzlük

${ }^{6}$ Usulsüzlük ve özel usulsüzlük cezaları 7103/15.madde ile uzlaşma kapsamından çıkarılmışlardır. Böylelikle tarhiyat öncesi uzlaşma ve tarhiyat sonra uzlaşma arasında usulsüzlük ve özel usulsüzlük cezaları arasında ayırıma gidilmesine yönelik uygulama farklılığı ve eleştiriler çözümlenmiş oldu.

${ }^{7}$ Beyanına baz almak üzere takdir komisyonundan matrah takdir talebinde bulunan mükellef takdir komisyonu kararı üzerine tarh edilen vergi/ceza üzerine uzlaşma talebinde bulunabileceği hk. D.4.D,2009/8579E, 2012/1452K. 
cezaları $7103^{8}$ sayılı kanunla yapılan düzenlemeden sonra uzlaşma kapsamı dışına alınmışlardır. VUK, 359. madde kapsamındaki cezaların kapsam dışı bırakılmasının Uzlaşma Kurumunun getiriliş amacıyla örtüştüğü ifade edilebilir.

\section{Uzlaşma Komisyonları}

Uzlaşma Kurumunun işlerliği özel olarak oluşturulmuş uzlaşma komisyonlarınca sağlanır. Uzlaşma toplantısında vergi idaresi uzlaşma komisyonları aracılığıyla temsil edilir. Mükellef ile vergi idaresinin uzlaştırılması görevinin, uzlaştırıcı olarak tanımlanan bir kişiye/ arabulucuya değil bir komisyona yüklenmiş olması vergi hukukunda uygulanmakta olan uzlaşma kurumunu diğer hukuk dallarındakinden ayırt edici unsurlarından biridir. Komisyonların oluşumu uzlaşma başvurusunun tarhiyat öncesi aşamaya veya tarhiyat sonrası aşamayla ilgili olmasına göre değişir.

\subsection{Uzlaşma Komisyonlarının Oluşumu}

Tarhiyat öncesi uzlaşma, vergi tarhiyatına hazırlık işlemi niteliğindeki vergi denetim mekanizmasının sadece vergi inceleme aşamasına özgülendiğinden olsa gerek uzlaşma komisyonları da vergi incelemesi yapmaya yetkililerden oluşmaktadır. Bu komisyonların oluşumu vergi incelemesini yapanların vergi müfettişleri ya da vergi incelemesi yapmaya yetkili diğer yetkililer olmasına göre değişmektedir ${ }^{9}$. Tarhiyat öncesi uzlaşma komisyonları vergi inceleme yetkililerinin geçici çalışma yerlerinde de oluşturulabilir.

Tarhiyat sonrası uzlaşma komisyonları, ikmalen, resen veya idarece tarh edilen vergi/ cezalar hakkında uzlaşma yetkisi verilen komisyonlardır. Komisyonların yetki alanları parasal sınırlar itibarıyla tanımlanmıştır. Bu komisyonların uzlaşmaya yetkili oldukları parasal sınırlar VUK Genel Tebliğlerinde düzenlenmiştir. Tarhiyat sonrası uzlaşma komisyonları; vergi dairesi uzlaşma komisyonu, defterdarlık uzlaşma komisyonu, vergi dairesi başkanlığı uzlaşma komisyonu, vergi daireleri koordinasyon uzlaşma komisyonu ve merkezi uzlaşma komisyonundan oluşur. Yetkili uzlaşma komisyonunun hangisi olduğu, tarh edilen vergi ve cezanın parasal miktarına göre ayrıştırılmıştır ${ }^{10}$.

\subsection{Uzlaşma Komisyonlarının Toplanması}

Komisyonun toplanabilmesi mükellefin kanunun aradığı şartlara sahip yazılı başvurusuna bağlıdır, böyle bir başvuru olmadan komisyon toplanamaz. Uzlaşma toplantısı yasal şartlara sahip uzlaşma başvurularının mükellefle pazarlık esasına göre değerlendirildiği aşamadır. Uzlaşma komisyonları komisyon üyeleri ile mükellefin hazır bulunması üzerine toplanır. Uzlaşma komisyonları (tarhiyat öncesi ve tarhiyat sonras1), üyelerinin tamamının katılımı ile toplanır. Komisyon üyelerinden birinin toplantıya katılamaması durumunda bunlara vekalet eden üye komisyonda görev alır

87103 Sayılı Kanun,m.15, 27.3.2018T, 30373 nolu mük. RG

9 Tarhiyat Öncesi Uzlaşma Yönetmeliği, 31.10.2011Tarih 28101 Numaralı Resmi Gazete, m.5-6.

${ }^{10}$ Uzlaşma Yönetmeliği, m. 3. 2.1999Tarih, 23600Numaralı Resmi Gazete ile 4. 4.2015Tarih 29316 Numaralı Resmi Gazete. 
(TÖUY, m.14/2, TSUY,m.6). Uzlaşma komisyon üyesi ile uzlaşma başvurusunda bulunan arasında VUK/6.madde kapsamında vergi mahremiyeti kapsaminda kalan bir bağlantı durumu tespit olunursa ilgili mükellefle ilgili Komisyon toplantısına başka bir üyenin katılması sağlanır.

Uzlaşma komisyonu toplantısı, komisyon üyelerinin tamamı ile mükellef, temsilcisi, mükellefin dilemesi durumunda bağlı olduğu meslek odasından bir temsilci ile 3568 sayılı yasa uyarınca yetki almış bir meslek mensubunun katılımı ile yapılır. Ancak bunlar toplantıda sadece görüş açılayabilirler, uzlaşma sonunda düzenlenecek uzlaşma tutanağını imzalama yetkileri bulunmamaktadır (TÖUY, 14).

Uygulamada zaman zaman belirlenen yer ve zamanda komisyonların toplanamadığı durumlarla karşılaşılmaktadır. Uzlaşma toplantısının komisyondan kaynaklanan nedenle yapılamaması durumunda İdarenin yasal prosedürü tamamlama ve mükellefe yasayla tanınan bir haktan mahrum edilmemesi için mükellefe yeni bir toplantı gününün belirlenerek bildirilmesi gerekir (Kızılot, 2000:1076).Uzlaşma komisyonları uzlaşma komisyonunu toplama görevinden kaçınamayacakları gibi, mükelleflere tanınan hakları sınırlayamazlar, mükelleflerin bu haklarını kullanmalarını engelleyemezler. Uzlaşma komisyonu mükellefin mücbir sebep hali olarak kabul edilen bir durum nedeniyle toplanamamış ise, mükellefe uzlaşma toplantısı için yeni bir gün belirlenerek bildirilir (TÖUY, 14/3). Mükellefin herhangi bir bildirimde bulunmaksızın veya mazeret belirtmeksizin toplantıya katılmaması durumunda uzlaşma toplantısı için yeni bir zaman belirlenmez.

Uzlaşma görüşmelerinin genel olarak belirlenen günde sonuçlandırılması esastır. Bunun mümkün olmaması veya daha ayrıntılı inceleme yapılmasını gerektirmesi durumunda başka bir gün de belirlenerek ertelenebilir (TSUY, 11). Komisyonun defter, kayıt ve belgeleri vergi incelemesi kapsamında inceleme yetkisi olmadığından komisyonun yapacağı inceleme uzlaşma başvurusunu tamamlama amacıyla sinırlı niteliktedir.

Uzlaşma konusu verginin matrah farkları itibarıyla bölünebildiği durumlarda uzlaşmanın sadece toplam matrah farkının bölünebilen kısmına isabet eden tutar için yapılabileceği esasını benimseyerek kısmi uzlaşmaya imkan tanınmıştır (VUK, ek-1; TÖUY, 16/6). Böylelikle, birden fazla nedenle vergi ve cezaya muhatap kalan mükellefin, nedenlerden birisine karşı çıkması, diğerlerini kabul etmesi mümkün kılınmıştır. Bu nedenle komisyonda karara bağlanacak uzlaşma konusunun kapsamı kanunda belirtilen ve mükellefin başvurduğu kısımla sınırlıdır.

Tayin edilen uzlaşma gününde mükellef/ vekili ve dilemesi durumunda 3568 Sayılı Yasaya göre yetki almış bir meslek mensubu ve üyesi olduğu Oda'nın bir temsilcisiyle belirlenen yerde komisyon toplantısına katılır (TSUY, m,10; TÖUY,15). Komisyon mükellefe tarh edilen /edilecek olan vergi/ceza tutarıly ilgili olarak terkin edilecek tutar üzerinden teklifini sunar, pazarlık esasında bu teklif görüşülerek bir karara bağlanmaya çalışılır. 
Uzlaşma toplantısının sonucu (tarhiyat öncesi veya tarhiyat sonrası) uzlaşmanın sağlanması veya sağlanamaması şeklinde görünüm kazanır.

\subsection{Uzlaşma Komisyonlarının Kararları}

Uzlaşma komisyonları mükellefe teklif edecekleri tutarı belirlerken ölçülülük ilkesine ${ }^{11}$ aykırılık oluşturmayacak biçimde, anayasa genel ilkeleriyle birlikte 73.maddesindeki vergi ödevini düzenleyen maddede belirtilen ilkeleri ve hukukun genel ilkelerini göz önünde bulundurmakla yükümlüdürler. Bu çerçevede komisyon, kararının uzlaşma kurumunun amacıyla uyumlu ve orantılı olmasına, makul bir süre içinde verilmesine ve gerekçeli olarak ortaya konulmasına dikkat etmelidir (Gerçek, 2010: 37).

Komisyonda mükellefe teklif edilen tutar komisyon üyelerinin ortaklaşa kararını oluşturur. Komisyon üyeleri arasında teklif edilecek kısım üzerinde görüş birliği sağlanamasa dahi kararın alınması için çoğunluk kararı yeterli olacağından (TÖUY, 14/1) üç kişilik komisyon üyelerinden ikisinin, kararı oluşturacak tutar üzerinde görüş birliği içinde olmaları yeterlidir.

Komisyon kararının kapsamı mükellefin başvurusunda belirtilen kısımla sınırlıdır, başvuruda belirtilmeyen vergi/ceza kısmı hakkında olamaz. Komisyon kararı vergi uygulamasıyla ilgili konu hakkında vergi/cezanın ne kadarlık kısmın terkin edilebileceği ile ilgili bir hesaplama işlemi sonucunu ifade eder.

Uzlaşma komisyonları mükellefe önerilecek vergi/ceza tutarını belirlemeden önce toplantıya katılan mükellef ve temsilcisini dinlerler. Komisyon üyeleri mükellefle yapılan uzlaşma görüşmesini değerlendirerek teklif edecekleri tutarı belirler ve bu tutar üzerinde uzlaşılacak vergi/ ceza tutarı komisyonun kararını oluşturur. Karar bu aşamada komisyonun mükellefe teklifi mahiyetindedir. Komisyonun teklif ettiği tutar uzlaşma tutanağına yazılır ve kesin niteliği kazanır. Mükellefin tutanağı imzalamaması veya teklifi reddetmesi düzenlenen tutanağın kesinlik niteliğini etkilemez, sadece uzlaşma sağlanamamış olur.

\section{Uzlaşmanın Tarafları}

Uzlaşma toplantısının muhatabı vergi mükellefi ile vergi idaresini temsilen yetkili uzlaşma komisyonlarıdır. Vergi mükellefi ile komisyonun yasada belirtilen şartlara sahip olarak belirtilen zamanda hazır bulunmaları ile uzlaşma görüşmesi yapilır.

\footnotetext{
${ }^{11}$ Orantılılık, elverişlilik, ve gereklilik unsuru bulunan ölçülülük ilkesi, kişilerin çıkarları ile kamu yararı arasında makul bir denge kurulması ve adaletin sağlanmasını ifade eder (Gerçek, a g m, s.27). Anayasa madde 13 "temel hak ve hürriyetlere ilişkin yapılabilecek sınırlamaların hak ve hürriyetlerin özüne dokunmadan Anayasanın ilgili maddelerinde belirtilen sebeplere bağlı olarak ve ancak kanunla sınırlanabileceği ve bu sınırlamanın da Anayasanın sözüne, ruhuna ve demokratik toplum düzeninin ve laik Cumhuriyetin gereklerine ve ölçülülük ilkesine aykırı olamayacağı hakkında".
} 


\subsection{Vergi Mükellefi}

VUK, 8.maddesinde mükellef kavramının vergi sorumlusu kavramını kapsadığı belirtilmiştir. Buna uygun olarak Uzlaşma Yönetmeliği (tarhiyat sonrası) tanımlar bölümünde mükellef, kendisine vergi borcu düşen gerçek veya tüzel kişilerle sorumluları ve müteselsil sorumluları kapsar biçimde ifade edilmiştir.

Normal şartlarda verginin mükellefi ilgili vergi itibarıla cezanın da muhatabıdır. Ancak vergi uygulamaları açısından vergi mükellefi ile ceza muhatabının farklı kişiler olması mümkündür. Vergi mükellefi ile ceza muhatabının farklı kişiler olması durumunda mükellef/ceza muhatabı olan kişinin doğru tespiti önem taşımaktadır. Vergi hukukunda vergi mükellefi olabilmek için kanuni ehliyet şartı aranılmamıştır (VUK, 9). Buna göre hak ehliyetine sahip olup fiil ehliyetine sahip olmayan kişiler de vergi mükellefi olabilmektedir. Küçükler, kısıtlılar gibi gerçek kişiler ile tüzel kişiliği bulunmayan vakıf ve cemaatler gibi varlıkların vergi ödevleri veli, vasi, kayyum veya vakıf ve cemaat varlıkları idare edenler gibi kanuni temsilcileri aracılığıyla yerine getirilir. Kanuni temsilcilerin ödevlerini yerine getirmemeleri nedeniyle mükellefin varlığından alınamayan vergi aslı ve asla bağlı alacaklar için öncelikle vergi mükellefine müracaat edilir, vergi mükellefinden alınamaması durumunda bu alacaklar için kanuni temsilciye müracaat olunur. Kanuni temsilcinin ödemek durumunda kaldığı tutarlar için vergi mükellefine rücu etme imkanı bulunmaktadır. Kanuni temsilcilerin vergi kanunlarına aykırı hareketleri nedeniyle kesilecek vergi cezaları (idari para cezası niteliğine sahip olanlar veya hürriyeti bağlayıcı nitelikteki cezalar) vergi mükellefi adına değil, kanuni temsilci adına kesilir ve kanuni temsilcinin bunlar için mükellefe rücu imkanı da bulunmamaktadır. Tüzel kişilerin kanuni temsilcilerinin vergi kanunlarına aykırı fiilleri nedeniyle kesilen vergi aslına bağlı alacak ve vergi cezaları kanuni temsilci adına değil tüzel kişilik adına kesilir. Kesilen vergi cezası hürriyeti bağlayıcı nitelikteki ceza ise bu ceza cezaların şahsiliği ilkesi gereğince ilgili kanuni temsilci adına kesilir ${ }^{12}$.

\subsection{Uzlaşma Komisyonları}

Uzlaşma komisyonları uzlaşma sürecinin aksamadan yürütülmesi ve uzlaşma kurumunun amacına ulaşması göreviyle yükümlendirilmişlerdir. Mükelleflerce yapılan uzlaşma başvuruları ilgili sekretarya tarafından incelenerek yasal açıdan uygun şartları taşıyanlar uzlaşma toplantısına davet edilir. Belirlenen tarihte mükellef/temsilcisinin katılımıyla toplanırlar. Uzlaşma toplantısının sonunda tutanak düzenleyerek uzlaşma toplantısını sonlandırırlar.

\footnotetext{
12 VUK,10-332-333
} 


\section{Uzlaşma Süreci}

Tarhiyat öncesi uzlaşma ile tarhiyat sonrası uzlaşma kurumu açısından uzlaşma sürecinin işleyişi bazı konular bakımından farklılaştırılmıştır ${ }^{13}$. Ancak her iki uzlaşma süreci de mükellefin uzlaşma başvurusunda bulunması ile başlayıp başvurunun değerlendirilmesi, uzlaşma toplantısının yapılması ve komisyon kararının alınması ile sonuçlanır.

\subsection{Uzlaşma Başvurusu}

Tarhiyat öncesi uzlaşma başvurusu, mükellef veya vekili tarafından, incelemeyi yapana veya bağlı bulunduğu birime yada Grup Başkanlığına, inceleme tutanağının imzalanmasına kadar yapılabilir (TÖUY, m.8).

Tarhiyat öncesi uzlaşma başvurusunda bulunma kararı mükellefin kararı üzerine alınabileceği gibi vergi inceleme yetkilisinin önerisi üzerine de alınabilir (TÖUY, 9/2). Tarhiyat öncesi uzlaşma başvurusunda bulunma kararını mükellef kendi iradesi ile almışsa (herhangi bir davet almaksızın) bu başvuruyu incelemenin başlangıcından vergi incelemesiyle ilgili son tutanağın düzenlenmesine kadar geçen süre içerisinde yapabilir (TÖUY, 9/1). Eğer mükellefe uzlaşma daveti vergi inceleme yetkilisince yazılı olarak yapılırsa, (ancak sonuçlanmak üzere olan vergi incelemelerinde tarh zamanaşımının dolmasına üç aydan az bir zaman kalmışsa mükellef uzlaşmaya davet olunmaz(TÖUY,9/3), mükellef davet yazısının tebliğ edildiği tarihten itibaren onbeş gün içerisinde uzlaşma başvurusunda bulunabileceği belirtilmiştir (TÖUY, 9/2). Mükellefin bilgisi dışında yürütülmekte olan, harici bilgilere dayanılarak yapilan inceleme sonucunda vergi incelemesi yapanın mükellefi uzlaşmaya davet etmesi de mümkündür. Bu durumda mükellefe davet yazısının uzlaşma gününden en az onbeş gün önce tebliği gerekir (TÖUY, 11). Uzlaşma başvurusunun dilekçe ile yazılı olarak yapılması esastır. Ancak, inceleme yetkilisinin davetinin kabulü üzerine yapılacak başvurular için zorunlu ve geçerlilik şartı olarak kabul edilen yazılılık şartı inceleme tutanağında başvurunun belirtilmesiyle yerine getirilmiş sayılır (TÖUY, 8/1-2). Burada önemli olan bir diğer husus uzlaşma başvurusuyla birlikte vergi inceleme raporunun da ilgililere tebliğ edilmiş olmasıdır.

Tarhiyat sonrası uzlaşma için mükellef ${ }^{14}$ vergi/ceza ihbarnamesinin tebliğ tarihinden itibaren otuz gün içinde başvurusunu yapması gerekir (VUK, ek-1). Uzlaşma başvurusunun yetkili uzlaşma komisyonuna yapılması gerekmektedir. Tarhiyat sonrası uzlaşma komisyonlarının uzlaşma yetkileri parasal limitler şeklinde

${ }^{13}$ DVDDK $^{13}$ bir kararında Tarhiyat sonrası uzlaşma kurumu ile tarhiyat öncesi uzlaşma kurumunu farklı kurum olarak nitelemiştir. Buna göre, tarhiyat sonrası uzlaşma kurumunun düzenlenme amacıyla planlanan hedefin istenen ölçüde sağlanamaması üzerine 3239 Sayılı Kanunla VUK. ek 11.maddesi ile buna tarhiyat öncesi uzlaşma kurumunun kabul edildiği, her ne kadar söz konusu kurum uzlaşma kurumu olsa dahi getiriliş amacındaki farklılık nedeniyle uygulama esaslarında farklılık olması (uzlaşmanın konusu, komisyonların oluşturulması, uzlaşma başvuru süresi, uzlaşma davetine uyulmaması gibi) ve uygulamanın da bu farklı esaslara göre yapılmasının olağan olduğu ifade edilmektedir.

${ }^{14}$ Şirket tüzel kişiliğini birlikte imza ile yönetmeye yetkili olanlarca yapılacak uzlaşma başvurusunun da birlikte imzalı dilekçeleriyle yapılması gerekeceği hakkında karar için bkz. D3D.E.1990/1800,K.1992/259 
belirlenmiştir. Yetkili komisyonun hangisi olduğuna dair tespitin mükellefçe tarh edilen vergi/ceza tutarına göre yapılması gerekmektedir. Kanuni niteliklere sahip uzlaşma başvuruları mükellefin bağlı olduğu vergi dairesine veya yetkili uzlaşma komisyonunun ilgili sekretaryasına verilir.

Tarhiyat sonrası uzlaşma başvurusunun ikmalen, resen veya idarece vergi ve vergi ziyaı cezasının Kanunun saydığı durumlar nedeniyle meydana çıkmış olması şartı aranmaktadır. Bu şartlar kanunun ek-1.maddesinde sayılmak suretiyle şu şekilde belirtilmiştir; kanun hükümlerine yeterince nüfuz edememek, VUK, 369. maddede yazılı yanılma halinin bulunması, VUK/ 116, 117 ve 118. maddelerinde yazılı vergi hataları ile bunun dışında her türlü maddi hata bulunması, uyuşmazlık konusu olayda yarg1 kararları ile idarenin görüş farklılığı olduğunun iddia edilmesidir.

\subsection{Uzlaşma Başvurusunun Değerlendirilmesi}

Uzlaşma başvurusunun yasal başvuru şartlarına sahip olup olmadığı incelenmeden uzlaşma başvurusu cevapsız bırakılamaz. Tarhiyat öncesi uzlaşma başvurusunun alınması üzerine uzlaşma günü belirlenir. Onbeş günden az olmamak üzere, uzlaşma günü ve saati mükellefe yazı ile bildirilir. Vergi inceleme raporunun da mükellefe tebliğ edilmesi gerekir. Mükellefin kabul etmesi durumunda süreye bağlı kalınmaksızın daha önceki bir tarih de uzlaşma günü olarak belirlenebilir (TÖUY, 10). Belirlenen uzlaşma tarih, gün ve saatinin mükellefe tebliğ edilmesi gerekir.

Tarhiyat sonrası uzlaşma başvurusu, talebin yasaya uygun şekilde ve süresi içinde yapılıp yapılmadığı, uzlaşma başvurusunun komisyonun yetkisi içinde bulunup bulunmadığı, uzlaşma başvurusunda bulunanın uzlaşma başvurusunda bulunma yetkisine sahip olup olmadığı, tarh edilen vergi/ cezanın uzlaşma kapsamına girip girmediği gibi konular bakımından incelenir. Başvuru şartlarının bulunup bulunmadığının tespitine yönelik bu inceleme ilgili sekretarya tarafından yapılır ${ }^{15}$. Sekretarya inceleme sonucuna ilişkin raporunu yetkili uzlaşma komisyonuna sunar. İlgili sekretaryanın "nitelikli karar verme yetkisi"16 bulunmadığından nihai değerlendirme yetkili uzlaşma komisyonunca yapılır. Yapılan değerlendirme sonucunda yasal şartlara sahip bulunan uzlaşma başvuruları için uzlaşma günü tespit edilerek mükellef uzlaşma görüşmesine davet olunur. Uygun bulunan uzlaşma başvuru talebi için onbeş günden az olmamak üzere uzlaşma tarih, gün ve saati belirlenir ve mükellefe bildirilir (mükellefin istemesi durumunda komisyon toplantısı onbeş günlük süreye bağlı kalınmaksızın daha önceki bir tarih uzlaşma günü olarak da belirlenebilir (TSUY, m.8-10). Başvuru şartlarına sahip olmadığı tespit olunan uzlaşma

\footnotetext{
15 Sekreterya hizmetleri; Vergi dairesi uzlaşma komisyonlarında vergi dairesi müdürlükleri, bağımsız vergi dairesi bulunmayan ilçelerde mal müdürlükleri, defterdarlık uzlaşma komisyonunda gelir müdürlükleri, vergi dairesi başkanlığı uzlaşma komisyonunda ilgili grup müdürlükleri, vergi daireleri koordinasyon uzlaşma komisyonu ve merkezi uzlaşma komisyonunda gelir yönetimi daire başkanlığınca yerine getirilir(TSUY,8); Tarhiyat öncesi uzlaşmalarda vergi müfettişlerinin dahil oldukları Grup Başkanlıklarının bulunduğu yerlerde yaptıkları vergi incelemeleri için oluşturulan komisyonlar için Grup Başkanlıklarınca, geçici çalışma yerlerinde yaptıkları incelemeler için oluşturulan komisyonlar için Ekip Başkanlıklarınca yürütülür(TÖUY,20).

${ }^{16}$ D7D,E.1986/973, K.1988/529
} 
başvurusuna ilişkin talep reddedilir. Uzlaşma başvurusunun reddi, başvurudan vazgeçme ile uzlaşmanın sağlanamaması doğurdukları hukuki sonuçlar bakımından farklı anlam taşırlar. Uzlaşma başvurusunun reddi uzlaşma başvurusunda bulunma yasal şartlarına sahip olmadığı halde yapılan başvuru taleplerinin uzlaşma komisyonun toplanmasina gerek kalmadan reddedilmesidir. Bu durumda başvurusu uzlaşmadan yararlanma şartlarına sahip bulunmadığı için reddedilen mükellef genel hükümler çerçevesinde dava açma süresini de kaçırmış olabilir. Uzlaşmanın sağlanamaması durumunda uzlaşma toplantısının tarafını oluşturan mükellefe dava açma süresi bitmiş veya onbeş günden az kalmış olması durumunda dava açma süresinin onbeş gün daha uzaması hakkı tanınmıştır (VUK, ek.m.7). Başvurusu reddedilen mükellefler ise bu haktan yararlanamazlar. Böyle bir durumla karşılaşmak istemeyen ve başvurusunun uzlaşma başvuru şartlarına sahip olup- olmadığından emin olamayan mükellef belki de dava açma hakkından mahrum kalmamak adına aynı anda dava açma ve uzlaşma başvurusunda bulunmayı düşünebilir. Böyle bir başvuru için yasal bir engel bulunmadığı gibi mükellefe ek bir maliyeti de bulunmamaktadır ${ }^{17}$.

Tarhiyat öncesi uzlaşma başvurusunda bulunan mükellef belirlenen uzlaşma tarihinden önceki bir tarihte yazılı olarak vergi inceleme raporunu düzenleyene veya Komisyona başvuruda bulunarak uzlaşma başvurusundan vazgeçtiğini bildirmesi durumunda uzlaşma başvurusunda bulunmamış sayılır ${ }^{18}$. Uzlaşma başvurusunda bulunmamış sayılma ile uzlaşmanın sağlanamamış olması arasında mükellefin tarhiyat sonrası uzlaşma başvurusunda bulunma hakkını kaybetmesi açısından önemli bir fark ortaya çıkmaktadır ${ }^{19}$.

\subsection{Uzlaşmanın Sonuçlanması ve Uzlaşma Tutanağının Düzenlenmesi}

Uzlaşma toplantısı (tarhiyat öncesi veya tarhiyat sonrası) hiçbir zaman sonuçsuz bırakılamaz, uzlaşmanın sağlanması veya sağlanamaması şekillerinden biri ile sonuçlandırılır.

\subsubsection{Uzlaşmanın Sağlanması}

Komisyonun teklif ettiği vergi/ ceza tutarının mükellefçe kabul edilmesi uzlaşmanın sağlanması durumudur. Mükellefin uzlaşma toplantısında komisyonca önerilen vergi/ceza tutarını komisyonda değil ancak dava açma süresinin sonuna kadar kabul etmesi de uzlaşmanın sağlanması olarak kabul edilir (TÖUY, 16/9, TSUY, 10). Bu uygulama mükellefe uzlaşma toplantısı sona erdikten sonra konu üzerinde tekrar düşünerek kararını irdelemesi konusunda zaman vermesi açısından önemli bir uygulamadır. Uzlaşmanın sağlanması durumunda; üzerinde uzlaşılan vergi/ceza kesinleşmiş olur. Komisyon uzlaşma görüşmesini yaparak üzerine kanunla yüklenen bir görevi yerine getirmiş olur. Mükellef, komisyon ile üzerinde anlaşmış oldukları

\footnotetext{
17 Mükellef tarafından aynı vergi ve ceza için uzlaşma talebinden önce dava açılmışsa dava, uzlaşma işleminin sonuca bağlanmasından önce vergi mahkemelerince incelenmez, herhangi bir sebeple incelenir ve karara bağlanırsa bu karar hükümsüz sayılır(TSUY,13).

18 Tarhiyat Öncesi Uzlaşma Yönetmeliği, m.12/ 3

19 VUK/ek-m.11-son
} 
vergi/ceza miktarını ödemeyi kabul etmiş olur. Bu durumda mükellef uzlaşılan vergi/cezayı ödemek veya teminat göstererek daha sonraki bir tarihte ödemek durumunda kalır (VUK/112 çerçevesinde). Tanınan yasal süre içerisinde mükellefin uzlaşılan tutarı ödememesi uzlaşma görüşmesini geçersiz kılmaz. Mükellefin bunu yasal süresinde ödememesi durumunda idare 6183 sayılı kanun hükümleri çerçevesinde mükellef hakkında cebri takibat sürecini başlatır. Uzlaşmanın sağlanamaması durumunda ise mükellef alternatif yasal yollardan hangisini izlemeye karar vermişse o doğrultuda hareket eder.

\subsubsection{Uzlaşmanın Sağlanamaması}

İlgili yasal düzenlemede mükellefin komisyonun davetine icabet etmemesi, uzlaşma tutanağını imzalamaması veya ihtirazi kayıtla imzalamak istemesi durumunda uzlaşma sağlanamamış kabul edileceği ifade edilmiştir (TÖUY, 16/3, TSUY,10). Uzlaşma başvurusunda bulunan mükellefin belirlendiği tarihte nedensiz olarak uzlaşma toplantısına katılmaması da uzlaşmanın sağlanamaması olarak kabul edilir. Mükellefe uzlaşmaya davet yazısının mükellefin bilinen adresine tebliğ edilememesi durumunda uzlaşma temin edilmemiş sayılır (TÖUY,12). Uzlaşmanın sağlanamadığına ilişkin tutanak hem mükellefe hem de incelemeyi yapana tebliğ edilir. Vergi incelemesini yapan kişi uzlaşmanın sağlanamadığına ilişkin tutanakla birlikte vergi inceleme raporunu vergi dairesine gönderir(TÖUY,13-16).

Harici bilgilere dayanılarak yapılan vergi incelemesi yapan yetkilinin uzlaşma davet yazısının mükellefe tebliğ edilememesinin Tarhiyat öncesi uzlaşma sağlanamaması olarak niteleneceği belirtilmiştir (TÖUY,2/1-2). Bu şekilde uzlaşmanın sağlanamamış sayılması nedeniyle mükellef tarhiyat öncesi uzlaşma toplantısından haberdar dahi olamadan (mükellefin bilgisi dışında yapılan vergi incelemesine davet edilmesinde olduğu gibi) mahrum kalmanın dışında bunun akabinde tarh edilecek vergi/ ceza hakkında tarhiyat sonrası uzlaşmaya başvurma imkanından mahrum olma gibi bir sonuçla karşılaşmaktadır.

Uyuşmazlığın çözümünde uzlaşma yolunu seçen ancak komisyonla uzlaşma sağlayamayan mükellefin yetkili vergi mahkemesinde yasal süre içerisinde dava açma hakkı bulunmaktadır. Uzlaşma başvurusunda bulunan mükellef cezada indirim talebinde bulunamaz. Ancak, uzlaşma başvurusunda bulunduktan sonra uzlaşma başvurusundan vazgeçtiğini bildiren mükellef yasal süresi içerisinde kalmak şartıyla cezada indirim talebinde bulunabilir. Uzlaşma başvurusunda bulunan mükellef uzlaşma sağlanamadığına dair tutanağı imzalayacağı tarihe kadar bundan vazgeçerek cezada indirim talebinde bulunabilir (Cezada indirim yasal başvuru süresi içinde kalmak şartıyla).

\subsubsection{Uzlaşma Tutanağının Düzenlenmesi}

Uzlaşma tutanağı yapılan uzlaşma toplantısı sonucunda uzlaşma komisyonunca düzenlenen bir belgedir. Uzlaşma tutanağının kapsamı mükellefin uzlaşma başvuru kapsamıyla sınırlıdır. Düzenlenen uzlaşma tutanağında mükellef kimlik ve adres bilgileri, ünvanı, uzlaşma talebi, konusu, uzlaşma sağlanan vergi-ceza 
miktarı, uzlaşma sağlanamaması durumunda komisyonun nihai teklifi, tarhiyat öncesi uzlaşmada incelemeyi yapana ait kimlik bilgilerine yer verilir.

Uzlaşma sağlansa da sağlanmasa da tutanağın toplantının taraflarını oluşturan komisyon üyeleri ve mükellef/veya vekili tarafından imzalanması gerekir. Tutanağın mükellef tarafından imzalanmaması durumunda tutanak mükellefe posta aracılığıyla tebliğ edilir. Tarhiyat sonrası uzlaşma toplantısı sonucunda düzenlenen uzlaşma tutanağı biri komisyonda kalmak, diğeri mükellefin bağlı olduğu vergi dairesine gönderilmek, diğeri de komisyonda mükellefe tebliğ edilmek üzere üç nüsha düzenlenir (TSUY, 10/6). Mükellefin imzadan kaçınması durumunda iki nüsha gerekli işlem yapılmak üzere vergi dairesine gönderilir. Tarhiyat öncesi uzlaşma tutanağ komisyon başkan ve üyeleri ile mükellef veya vekilince imzalanmasının ardından bir nüshası mükellefe derhal verilir, bir nüshası vergi inceleme raporuyla birlikte vergi dairesine gönderilir. Tutanakla tespit edilen vergi/ceza kesinleşmiş olur ve bu nedenle ödenmesi gerekir. Genellikle fiili/maddi durum tespiti amacıyla düzenlenen tutanaklar, tarafların karşılıklı okuyup imzalamalarını gerektiren belgelerdir. Zira tutanakta belirtilen hususlar bir haktan yararlanılmasına /hakkın kaybedilmesine yol açabilecek durumun tespitini/ hukuki zeminini içerirler. Vergilendirme sürecinde düzenlenen tutanakların( yoklama- vergi inceleme tutanakları gibi) içeriğine vergi mükelleflerinin itirazlarının bulunması durumunda bunu düzenlenen tutanakta belirtmeleri gereği daha sonraki aşamalarda haklarını arayabilmelerinin temel şartı olarak öngörülürken uzlaşma tutanaklarına şerh düşülerek imzalanmak istenmesi yasal açıdan uzlaşmanın sağlanamadı̆̆ı anlamını taşıyacağından buna imkan tanınmamıştır ki bu da uzlaşma tutanaklarını diğer tutanaklardan ayırt edici bir unsurdur.

Tarhiyat öncesi uzlaşma toplantısı henüz herhangi bir vergi/ ceza tarhiyatı yapılmadan önce vergi inceleme raporlarına dayanılarak, tarhiyat sonrası uzlaşma toplantısı ise vergi dairesince düzenlenen vergi/ ceza ihbarnamesine dayanılarak yapılmaktadır. Tarhiyat öncesi uzlaşmanın sağlanması sonucunda düzenlenen uzlaşma tutanaklarının "tahakkuk fişi" mahiyetine sahip olduğu belirtilmektedir (TÖUY, 19). Bu belirlemeyle, tahakkuk fişinin kesinliğini düzenleyen VUK/ 27.maddesi ile uzlaşma tutanaklarının kesin olma özelliği örtüşür niteliktedir. Ancak, tahakkuk fişi, beyan esasına dayanılarak verilen beyannamelerin tarh ve tahakkukunda düzenlenen bir belgedir (VUK, 25). Böylelikle verilen beyannamelerde yer alan vergi matrahlarına ilişkin bildirimlerle ilgili sürecin ödenecek aşamaya geldiğini ve bu işlemin kesin niteliğe sahip olduğunu (ihtirazi kayıt ve vergi hataları hariç) belirten bir belgedir. İkmalen- resen veya idarece tarh edilen vergi/ cezaların mükellefe bildirilmesinde kullanılan belgeler ise ihbarnamelerdir( vergi/ ceza) (VUK, 34).

Uzlaşma tutanaklarının kesin niteliğe sahip (tarhiyat öncesi veya tarhiyat sonrası uzlaşmada) olması tutanakta yer alan vergi/cezanın hiçbir mercie şikayet konusu edilmemesini ve vergi ve cezanın tahsili konusunda hem vergi idaresini, hem de mükellefi bağlayıcı niteliğe sahip olmasını ifade eder. Tarhiyat öncesi uzlaşmanın sağlanamaması durumunda düzenlenen uzlaşma tutanağı ise kesin ve yürütülmesi zorunlu işlemlerden olmadığından (Karakoç, 1995:126) idari işlem niteliği 
bulunmamaktadır. İdari işlem mahiyetine bürünmesi ancak vergi/ceza tarhiyatının vergi dairesince tarh edilmesinden sonra mümkün olabilmektedir.

Tarhiyat sonrası uzlaşmanın sağlanamaması durumunda, mükellefin alternatif çözüm yöntemlerine başvurusu ancak uzlaşma tutanağının tebliğ edilmesi ile işlerlik kazanabilir. Uzlaşma sonucunu içeren uzlaşma tutanağına istinaden vergi dairesince ayrıca vergi/ceza tarhiyatına dair ihbarname düzenlenmez, tutanak doğrudan mükellefe tebliğ edilir.

Uygulamada zaman zaman uzlaşma şartlarına sahip olmadığı halde üzerinde uzlaşılan vergi/cezalarla karşılaşılabilmektedir. Vergi dairesi uzlaşma şartlarına sahip olmadığ1 halde üzerinde uzlaşılan ${ }^{20}$ veya yetkisiz uzlaşma komisyonunca karara bağlanan uzlaşma tutanağı yöntemde paralellik ilkesi uyarınca tutanağı imzalayan taraflarca karşılıklı olarak geri alınmadıkça veya vergi dairesinin bunu hukuki uyuşmazlık konusu yapıp yargı organınca iptalini sağlamadıkça söz konusu tutanak ve tutanakla üzerinde uzlaşılan konu hüküm ifade edecektir ${ }^{21}$.

Kanun koyucu, bazı müesseseleri vergi sistemi içine yerleştirirken bu kurumların hukuki niteliğinden evvel pratik faydalarını ve iktisadi olgularını dikkate almaktadır (Yılmaz, 2009:335). Uzlaşma kurumunda da böyle bir fiili durumla karşılaşılmaktadır. Hukuki statüsünün ${ }^{22}$ belirlenmemiş olması düzenlenen uzlaşma tutanaklarında eleştiri konusu yapılacak hususların bulunması halinde bunların çözümlenmesinde belirsizlik ve duraksamaya neden olmaktadır. Şöyle ki, İdare hukukunda bir işlemin idari işlem olarak nitelenebilmesi için idari işlemin yetki, şekil, sebep, konu, amaç unsurları bakımından taşıması gereken bazı özellikler bulunmaktadır. Eğer, uzlaşma toplantısı sonucu düzenlenecek uzlaşma tutanağının idari işlem niteliğine sahip olduğu kabul edilirse idari işlemin kuruluşundan sonlandırılıncaya kadarki her aşamada idari işlemlere ilişkin prosedür uygulanacaktır. $\mathrm{Bu}$ durumda idare ile mükellef arasında çıkan ve üzerinde uzlaşılan vergi/cezalarla ilgili tutanakların iptal edilmesine yönelik taleplerin değerlendirilmesinde söz konusu uyuşmazlık idari işlemlerin tabi olduğu geri alma hükümlerine göre düzeltilecektir. Ancak, uzlaşma bazı Danıştay kararlarında da ifade edildiği gibi "sözleşme" niteliğine sahip kabul edilirse, uzlaşma sonunda düzenlenecek tutanak için idari işleme özgü geri alma şartları işletilemeyecektir (Yaltı/Özgenç, 2007:202). Bu nedenle konunun uygulanma sürecinde karşılaşılan problemler-özellikle uzlaşma tutanağının iptalinin talep edilmesi durumunda- yargı kararlarıyla aşılmaya çalışılmaktadır. Vergi Dava Daireleri Kurulu'nun (VDDK) ${ }^{23}$ bir kararında uzlaşma tutanağ sınırlı olmak üzere "bağlayıcı bir sözleşme" niteliğinde olduğu ifade edilmiştir(hem mükellef hem vergi idaresi açısından). Uzlaşma tutanakları iki tarafın karşılıklı özgür iradeleriyle imzalanmış sözleşme olarak tanımlanmış olması, tutanakların

\footnotetext{
${ }^{20}$ D7D,E.1986/973, K. 1988/529

${ }^{21}$ D9D,E.2002/805, K.2004/4955

${ }^{22}$ Uzlaşma kurumunun hukuki niteliğinin idari işlem, bir tür idari sözleşme(Öncel vd:2016,175), nev'i münhasır bir uygulama(takdir yetkisinin kullanımı açısından-Gerçek:2010,36) olduğu yönünde görüşler bulunmaktadır.

${ }^{23}$ DVDDK, E.2002/592,K.2003/333
} 
imzalanmasından sonra bunlarla ilgili olarak tespit edilecek hukuki aykırılıkların giderilebilmesinde her iki tarafın ortak iradesini gerektirecektir (Yaltı / Özgenç, 2007:201). Komisyon ile mükellefin uzlaştıkları vergi/ ceza üzerinde daha sonra yapacakları düzeltme, değiştirme, kaldırma talebiyle ilgili itirazlar uzlaşma tutanaklarının kesinliği ilkesi çerçevesinde her iki tarafı bağlayıcı niteliğe sahiptir. Ancak, uzlaşma kapsamında kalmayan bir konu üzerinde uzlaşmaya varıldığı sonradan anlaşılmış olabilir. Böyle bir durumda dahi İdare tek taraflı olarak uzlaşma tutanağını iptal etme yoluna gidemez (kaldı ki bu uzlaşma tutanaklarının kesinliği ilkesine de aykırıdır). Ancak hukuken batıl bir konu üzerinde uzlaşıldığının anlaşılması halinde bu durum konunun yarg1 merciine götürülebilmesi için "haklı sebebin" varlığını oluşturacaktır ${ }^{24}$.

\section{Takdir Yetkisi Kullanımı Açısından Uzlaşma Kurumu}

Takdir yetkisinin, herkes tarafından kabul görmüş bir tanımı bulunmamakla birlikte, bir hukuki durumla ilgili olarak kanunla, İdareye serbestçe faaliyette bulunabileceği bir hareket alanı tanıması, İdare'nin bu hukuki durumla ilgili olarak çeşitli davranış şekillerinden birisini seçebilme imkanına sahip olması olarak tanımlanabilir (Akyılmaz, 2000: 165).

İdare'ye belli bir davranışta bulunurken, yada belli bir görevi yerine getirirken az yada çok bir hareket serbestliği tanınmış ise "takdir yetkisinden" söz edilir (Gözübüyük, 1999:274). Bu anlamda takdir yetkisi ancak bir Kanunun düzenlediği herhangi bir Kanunun boş ve eksik bıraktığı veya İdareye bırakmakta isabet gördüğü noktalarında söz konusu olur. Takdir yetkisinde İdare, hukuk kurallarının belirlemiş olduğu sınırlar içinde ve işin icaplarına göre, çeşitli çözüm yollarından birini seçme veya tercih etme (ilkelerle sınırlı olmak üzere) yetkisine sahiptir (Gerçek, 2006: 25).

İdare takdir yetkisini Kanun Hükmünde Kararname, Tüzük, Yönetmelik, Bakanlar Kurulu Kararı, Genel Tebliğ, Genelge, Özelge, Sirküler gibi genel düzenleyici işlemler ile Uzlaşma, ilgili kanunlarda düzenlenmemiş sürelerin belirlenmesi, resen vergi tarhını gerektiren durumların varlığı, tecil, haciz, ihtiyati haciz, ihtiyati tahakkuk, teminat isteme gibi sübjektif bireysel işlemlerde kullanabilir. İdarenin Kanun Hükmünde Kararname, Bakanlar Kurulu Kararları, Tüzük, Yönetmelik gibi genel düzenleyici işlemleri yapabilmesine ilişkin takdir yetkisinin kaynağı Anayasa iken, Maliye Bakanlığına tanınan takdir yetkisinin kaynağı ilgili vergi kanunlarıdır. Maliye Bakanlığ1 kendisine ilgili vergi kanununa dayanarak tanınan takdir yetkisini Genel Tebliğ, Genelge, Özelge, Sirküler gibi genel düzenleyici işlemler aracılığıyla kullanabileceği gibi sübjektif bireysel işlemlerde de kullanabilir. Anayasa 73/3 hükmü gereği vergiler kanunla konulur, değiştirilir ve kaldırılır. Kanunilik ilkesi olarak tanımlanan bu ilkenin vergi hukukunda esas olması İdarenin takdir yetkisini sınırlandırmaktadır. Kanunilik ilkesi sonucu vergi idaresi bağlı yetkiyle donatılmış olup, takdir yetkisini istisnai hale getirmiştir (Şenyüz vd, 2017: 72).

\footnotetext{
${ }^{24}$ D4D,E.1999/653, K.1999/4781
} 
Yapılışı itibarıyla kolay olmayan üstün bir hukuk kaynağı olan vergi kanununun ilgili konuyu bütünü ve ayrıntılarıyla düzenlemesi mümkündür. Ancak teknik gerekler, değişkenlikte hız gereksinimi bu kaynaktan uzaklaşılmasına yol açmaktadır. Nitekim yönetimin bağlı düzenleme yetkisi yalnızca yasal metinlerle oluşturulamaz (Güneş, 1998:151). Kanun koyucunun her konuda çok ayrıntılı düzenleme yapamaması vergi idaresine takdir yetkisi tanımasının başlıca nedenini oluşturmaktadır. Düzenleme yapılacak hususların teknik konu veya detaylarla ilgili olması da bir başka nedenidir. İdareye takdir yetkisinin tanınmasının zorunluluk olduğu hususunda öğretide bir uzlaşı söz konusudur (Çelik, 2015:144). Yasal düzenlemenin durabileceği noktalar ödevliye masraf getirmemek, sosyal ve psikolojik maliyet yüklememek koşuluyla uygulamaya, ayrıntıya, tekniğe ve uzmanlığa ilişkin konulardır (Güneş, 1998: 134).

Takdir yetkisi idareye hukuka aykırılık yönünde bir istisna tanımaz, aksine idarenin hukuka bağlılığını arttıran bir unsurdur (Çelik, 2015:143). Takdir yetkisinin kullanılmasında ve sinırlandırılmasında hukuk devleti ilkesi, sosyal devlet ilkesi, eşitlik ilkesi, kararın gerekçeli olması ilkesi, kamu yararı amacı doğrultusunda ve hizmet gereklerine uygun olarak ve özel koşullar öngörülmüşse idarenin bunu dikkate alarak, kamu görevinin gereklerini dikkate almak suretiyle yasal çerçevede kullanma yükümlülüğünü kapsar (Akyılmaz, 2000:176-182; Gözübüyük-Tan, 2016:500). Takdir yetkisinin kullanımında İdarenin dikkat etmesi gereken bu ilkeler takdir yetkisi kullanımının sınırlarını oluşturmaktadır.

İdare'ye tanınan takdir yetkisi idari işlemin ancak "sebep" ve "konu" unsurunda olabilir, idari işlemin amaç, yetki ve şekil unsurlarında olamaz (Gözübüyük-Tan, 2016:512). İdare bu yetkisini hukuka uygun olarak kullanmak durumundadır. Takdir yetkisinin hukuka uygunluğu yapılan işlemin yetki, şekil kurallarına aykırılık, yetki veren kanun hükmüne aykırılık ve hukukun temel ilkelerine aykırılık noktalarından incelenerek tespit edilir (Gerçek, 2006: 30).

Vergi Usul Kanunu vergi idaresinin takdir yetkisini vergilendirmeye ilişkin ikincil sorunlara özgü olması kuralının bir istisnası olarak uzlaşma kurumunu kabul etmiştir (Güneş,1998: 178). Vergi idaresine sübjektif bireysel işlemlerle ilgili olarak tanınan takdir yetkisi genellikle vergi matrahının tayin edilmesi(resen vergi tarhı gibi) veya vergi/ceza alacağının güvenceye alınması konularında kullanılırken uzlaşma kurumunda vergi/ ceza miktarını (tarh edilen/edilecek olan) değiştirebilme (azaltılması) yönünde kullanılması söz konusudur.

Vergi hukukunda idareye en geniş takdir yetkisi verilen müesseselerin başında uzlaşma gelmektedir (Gerçek, 2006:36).Uzlaşma kurumunda takdir yetkisinin hem genel düzenleyici işlemlerde hem de üzerinde uzlaşılacak vergi/ceza miktarının tayin edilmesi suretiyle sübjektif bireysel işlemlerde kullanımı söz konusudur. Şöyle ki; uzlaşma kurumunun yasal dayanağı VUK ek-1-11. maddeleridir. Bu maddelerde uzlaşma konusu, başvuru şartları, uzlaşma konusunun kapsamı/sınırları, başvuru süresi, uzlaşma sonucu- uzlaşma sağlanmasi/ sağlanamaması, ve bu durumlarda yürütülecek işlemler, bu süreçte uzlaşma kurumunun işlerliğini sağlayan 
komisyonların görevleri, uzlaşma sonucunda uzlaşma tutanağı düzenlenmesi ve bunun niteliği, mükellefin hakları kanunilik ilkesi gereği yasa ile düzenlenerek kurumun işlerliği sağlanmıştır. Kanunda düzenlenen bu konular hakkında Uzlaşma Komisyonları "bağlı yetki" 25 ile donatılmışlardır. Bu hususlar hakkında "takdir yetkisi" yoktur. Maliye Bakanlığı, VUK, ek-1-11.maddelerince kendisine tanınan takdir yetkisini kullanarak tarhiyat öncesi ve tarhiyat sonrası uzlaşma yönetmeliklerini ve genel tebliğleri hazırlayarak uzlaşma kurumunun yürürlüğüne işlerlik kazandırmıştır. $\mathrm{Bu}$ yönetmeliklerde uzlaşma komisyonlarının oluşumu, uzlaşma başvurusunda bulunmaya yetkili olanlar, uzlaşmanın şekli, uzlaşmaya konu edilebilecek vergi, resim ve harçların belirlenmesi, uzlaşma komisyonlarının yetkileri, uzlaşma yapılmasına ilişkin usul ve esaslar gibi konular düzenlenmiştir.

Vergi Usul Kanununun uzlaşma kurumunu düzenleyen hükümlerinde “üzerinde uzlaşılabilecek vergi/ceza miktarının tespiti hususunda herhangi bir belirleme yapılmamış olması uygulamaya sınırları belirlenmemiş takdir yetkisinin sübjektif bireysel işlemlerde kullanımı şeklinde yansımaktadır.

\section{Uzlaşma Kurumunun Değerlendirilmesi}

$\mathrm{Bu}$ bölümde teorik ve uygulama esaslarını incelediğimiz uzlaşma kurumu ve komisyonlarının genel bir değerlendirmesi yapılacaktır.

Uzlaşma kurumunun, kavramsal olarak verginin tanımlanmasında ifade edilen, vergiyi diğer kamu gelirlerinden ayıran iki temel özellikten birisi olan, tüm vergilendirme sürecinde geçerliliğini koruyan ve kanunilik ilkesinin idareyi vergi tahsil ile yükümlendirdiği "cebir" unsuruyla çeliştiği ifade edilmektedir (Güneş, 1998: 180) . Cebir unsuru devlet yönünden vergiyi doğuran olayın vukuu bulması halinde vergilendirme sürecinin işletilmesi ve vergi gelirinin devletin kasasına girmesine kadar olan tüm aşamalarla ilgili görevlerini kapsar, vergi mükellefi bakımından bu verginin ödenmesine ilişkin zorunluluğu ifade eder. Uzlaşma kurumu ile devlet tahsil etmek zorunda olduğu vergi/cezanın bir kısmından vazgeçerken mükellef de tarh edilen /edilecek olan bir kısım vergi borcunun terkini nedeniyle ödeme zorunluluğundan kurtulmaktadır. Ayrıca, ülkemizdeki uygulama esası gereği uzlaşma kurumuna başvurunun zorunlu olmaması da bir başka özellikli durum olarak karşımıza çıkmaktadır. Zira, uzlaşmaya başvuru dava şartının veya uyuşmazlığın çözümünde takip edilebilecek işlemlerin ilk basamağı olarak da düzenlenmemiştir sistemimizde.

Uzlaşma kapsamına VUK/359. madde dışındaki sebeplerle tarh edilen/ edilecek vergi ziyaı cezaları girer. Usulsüzlük cezaları uzlaşma kapsamından çıkarılmıştır. İdare'nin mükellefin (tarhiyat sonrası uzlaşma için) vergi cezalarını yeniden tayin

\footnotetext{
${ }_{25}$ İdare'nin takdir hakkı, işlem yaparken "bağlı yetki” ve "takdir yetkisi” şeklinde karşımıza çıar. İdare Kanunda öngörülen şartlar meydana geldiğinde işlem yapmakla bağlıdır. Bu durumda İdarenin işlem yapmak zorunda olmasına "bağlı yetki" denir(Şenyüz vd.,2016:71). Bağlı yetki, yönetilenler için, keyfi yönetime karşı bir korunma, bir güvencedir. (Güneş, 1998: 151). Bağlı yetkinin kullanımında İdarenin işlemin "konu" unsuruna ilişkin seçme hakkı bulunmamaktadır. Yasal dayanağa bağlı olarak vuku bulmuş "konu” üzerinden işlemi yapmakla yükümlüdür. Bu durumda İdare işlemin konu unsurunu yok sayarak işlem yapmama veya daraltıcı-genişletici nitelikte işlemi değiştirici bir fiilde bulunamaz.
} 
etmesine yönelen yönüyle Anayasa $73 / 3$ ve 38. maddelerine aykırıdır (Saban, 2014: 568). Gerçek anlamda vergi suçları ve cezaları ancak anayasa ilkeleri çerçevesinde yetkili organlarca affedilebilecekken uzlaşma kurumu aracılığılla vergi cezalarının önemli bir kısmının terkin edilmesi ile vergi suç ve cezalarının, ceza hukuku anlamında ihlal ve yaptırım niteliği taşımayıp, idari yaptırım- idari kabahat oldukları yönündeki doktrindeki görüşe ağırlık kazandırmaktadır (Öncel vd, 2016: 175). Kaldı ki, Vergi Usul Kanunu 359. maddesinde sayılan fiillerle sebebiyet verilen vergi suçları ve cezaları uzlaşma kurumunun kapsamı dışında tutulmuş olması da bu görüşü destekler niteliktedir.

Kendilerine aynı tür ve miktarda vergi/ceza tarh edilen mükelleflerin uzlaşma kurumu karşısındaki durumlarının genel olarak görünümü şöyledir. Kendilerine aynı tür ve miktarda vergi/ceza tarhiyatıyla karşılaşan mükellefler yasal açıdan uzlaşma başvurusunda bulunma hakkı bakımından eşit konumdadırlar. Tarhiyatın durumu, mükellefin bu konuda tercih edeceği yöntemin gereği doğrultusunda şekillenecektir. Başvuru şartlarına sahip mükelleflerin birinin uzlaşma başvurusunda bulunup, diğerinin bulunmaması ve tarhiyat tutarını doğrudan ödemesi veya dava konusu yapması mükellefin kararının neticesini yansıtır. Aynı tür ve miktarda vergi/ceza tarhiyatıyla karşılaşan ve uzlaşma talebinde bulunan mükelleflerin farklı komisyonlarda farklı miktarlar üzerinde uzlaşmış olmaları veya bunlardan biriyle uzlaşma sağlanırken, diğeriyle sağlanamaması (her ne kadar pazarlık esasına dayalı da olsa) anayasal eşitlik ilkesine aykırılık teşkil edecek niteliktedir (Öncel vd, 2016: 175). Bu durumun önlenmesi komisyonun uzlaşabileceği vergi aslı ve cezasının belirli bir yüzdesi olarak veya hiç değilse uzlaşılabilecek alt ve üst sınırların belirlenmesi isabetli olacaktır. Böylelikle hem eşitlik ilkesi yönünden, hem de kanunilik ve hukuki güvenlik ilkelerine uygunluk sağlanabilecektir. Ancak, uzlaşma kurumunun temel işleyiş mekanizmasının pazarlık esasına dayalı olması faktörü de unutulmamalıdır ${ }^{26}$.

\section{Sonuç}

Uzlaşma, uygulama esasları farklılık göstermekle birlikte pek çok ülkede (ABD, Fransa, İngiltere vb) yaygın ve etkin şekilde uygulanmaktadır ${ }^{27}$. İdare-mükellef arasındaki vergi/ceza uyuşmazlığını en kısa zamanda ve yöntemle çözme iddia ve amacıyla düzenlenmiş bir kuruma ilişkin yasal düzenlemenin uygulama esaslarını kolaylaştırması gerekir. VUK, ek-1.maddesi uzlaşma başvurusunda bulunabilmek için çeşitli sebeplerin varlığını (kanun hükümlerine yeterince nüfuz edememe, yanılma halinin bulunması, vergi hatası veya bunun dışında maddi hata bulunması, yargı kararları ile İdare'nin ihtilaf konusu olayda görüş farklılı̆̆ının bulunması) aramaktadır. Bu ise uygulamada zaman zaman problem yaratmaktadır. Örneğin, vergi/ceza tarhiyatıyla karşılaşan ve tarhiyatta vergi hatası olduğunu iddia eden mükellef, hatanın düzeltme mekanizması aracılığıyla düzeltilmesi yerine tarhiyat sonrası uzlaşma kurumuna başvuru yolunu seçebilmektedir. Bu durum uzlaşma

\footnotetext{
${ }^{26}$ Gerçek, a.g.m.36

27 Hocaoğlu, Celal, http://dergipark.gov.tr/download/article-file/155581.Erişim.3.12.2018; Bu kurum Almanya'da Anayasaya aykırı bulunarak iptal edilmiştir(Öncel vd.a.g.e.s.174).
} 
kurumuna vergi hatalarının çözümünde başvurulacak başka bir alternatif yol (VUK düzeltme dışında) niteliği kazandırır mı? ${ }^{28}$ Kanımızca bu iki kurumun getiriliş amacındaki farklılık böyle bir nitelemeye imkan tanımamaktadır. Üzerinde uzlaşma sağlanmış olan bir vergi/cezada VUK 116-117-118 kapsamında vergi hatası bulunması durumunda ve bu konuyla ilgili verilmiş yargı kararı bulunmaması şartıyla bunun VUK madde 124 'te yer alan düzeltme hükümleri kapsamında ve düzeltme zamanaşımı süreci içinde düzeltilmesi talebinde bulunulabileceği konusunda yerleşik görüş bulunmaktadır ${ }^{29}$. Benzeri karışıklık diğer uzlaşma başvuru şartları için de söz konusu olabilmektedir. Oysaki, uzlaşma başvurusunda bulunabilmek için çeşitli sebeplerin varlığını aramak yerine, “İdare'nin vergi ziyaı tespitiyle (359.maddede fiillerle neden olunanlarla bunlara iştirak edenler hariç) vergi/ceza tarhına muhatap olanlarla[beyan esası hariç (ihtirazi kayıt ve vergi hataları dışında)] uzlaşabilmesinin" mümkün kılınması uygulama esaslarını kolaylaştıracaktır.

Uzlaşma kurumunun hukuki statüsü yasal düzenlemede belirtilmemiştir. Uzlaşmanın hukuki statüsünün yasal düzenlemede belirlenmemiş olması sonradan meydana çıkan problemlerin çözümü konusunda uzlaşma tutanaklarıyla ilgili işlemin nasıl yürütüleceği hususunda uygulamada belirsizliğe neden olmaktadır.

Uzlaşma kurumu ile tarh edilen/edilecek vergi/ceza miktarı değişmektedir. Kanunilik ilkesi gereği vergi miktarını değiştiren işlemlerin kanunla düzenlenmesi gerekirken İdarenin bu konuda takdir yetkisi kullanmasına sessiz kalınmıştır. İdareye takdir yetkisi verilebilir. Takdir yetkisi verilmesi işin doğası gereği olmakla birlikte sınırları tayin edilmemiş takdir yetkisi verilmesi kanunilik ilkesine aykırı nitelik taşımaktadır ${ }^{30}$.

Çalışmamız sonucunda uzlaşma başvurusuna ilişkin yasal düzenlemenin gözden geçirilmesi(tarhiyat sonrası uzlaşma özelinde), hukuki statüsüne belirlilik kazandırılması (özellikle tutanakla tespit edilen hususlarla ilgili sonradan ortaya çıkan ve düzeltilmesi gereken işlemler bakımından), uzlaşma komisyonlarına tanınan takdir yetkisinin sınırlarının belirlenmesi suretiyle bu kurumun vergi hukukuna sunacağı katkılar arttırılabilir.

\footnotetext{
${ }^{28} \mathrm{Bu}$ durumda uzlaşma başvurusunun mükellef bakımından makul bir yöntem olmadığ hakkında görüş için bakınız Yavaşlar, a.g.m.324

${ }^{29}$ D.3.D.,2005/2364E.,2006/942K. GİB, VUK.m.ek-1 hakkındaki Özelgesi.www.gib.gov.tr; ayrıca bkz. GİB, VUK.m.ek-6 hakkındaki Özelgesi.www.gib.gov.tr

30 Yetkili tarhiyat sonrası uzlaşma komisyonlarının uzlaşmaya yetkili oldukları parasal sınırlar genel tebliğlerle belirlenmektedir. Ancak belirlenen bu parasal tutarlar uzlaşma görüşmelerinde üzerinde uzlaşılabilecek tutarlar olmayıp, tarh edilen vergi/ceza miktarına göre yetkili olan uzlaşma komisyonun belirlenmesiyle ilgili tutarlardır.
} 


\section{Kaynakça}

Akyılmaz, B.(2000). İdari Usul İlkeleri Işı̆̆ında İdari İşlemin Yapılış Usulü. Ankara: Yetkin Yayınlar1

Çelik, N. K.(2015).İdarenin Takdir Yetkisinin Türk Vergi Hukuku Açısından Değerlendirilmesi, https://docplayer.biz.tr/8699143-Idarenin-takdir-yetkisinin-turk-vergi- hukukuacisindan-degerlendirilmesi.html (Erişim,3.12.2018).

Gerçek, A.(2010). Vergi Hukuku Alanındaki Takdir Yetkisinin Kullanılmasında İdarenin ve Memurun Sorumluluğu. Bursa: Uludağ Üniversitesi İ̈BF Dergisi, C. XXIX, S. 2

Gözübüyük, Ş. ve Tan, T.(2016). İdare Hukuku. Ankara: Turhan Kitabevi, C.2

Güneş, G. (1998). Verginin Yasallığı İlkesi. İstanbul: Alfa Yayıncılık

Hocaoğlu, C. Vergi Hukukunda Uzlaşma: http://dergipark.gov.tr/download/article-file/155581. Erişim. 3.12.2018

Karakoç, Y. (1995). Vergi Yargılaması Hukuku . İstanbul: Alfa Basım Dağıtım

Karakoç, Y. (2013). Anayasal Vergilendirme İlkeleri Üzerine Bir Değerlendirme. İzmir: Dokuz Eylül Üniversitesi Hukuk Fakültesi Dergisi, C.15, Özel Sayı

Kızılot, Ş. (1998, 2000, 2002, 2007). Vergi Uyuşmazlıklarıyla İlgili Danıştay Kararları ve Özelgeler (Muktezalar).Ankara: Yaklaşım Yayınları

Kızılot, Ş. (2000). Vergi İhtilafları ve Çözüm Yolları. Ankara: Yaklaşım Yayınları

Öncel M., Akkaya M., Çağan, N. (2016). Vergi Hukuku. Ankara: Turhan Kitabevi

Saban, N.(2014), Vergi Hukuku. İstanbul: Beta Yayıncılık, 8.Baskı

Şenyüz, D., Yüce, M., Gerçek, A.,(2016).Vergi Hukuku. Bursa: Ekin Kitabevi

Yaltı B. ve Özgenç S.(2007). Vergi Hukuku Pratik Çalışma El Kitabı. İstanbul: Beta Yayıncılık

Yavaşlar, F.B. (2008). Türk Vergi Hukukunda Uzlaşma. İstanbul: Marmara Üniversitesi İ̈BF Dergisi, C.XXV, S.2

Yılmaz, E. (2009). Uzlaşma Müessesesinin Hukuki Niteliği ve Temel Vergilendirme İlkeleri Açısından Değerlendirilmesi. Ankara: Gazi Üniversitesi Hukuk Fakültesi Dergisi. C.XIII

Danıştay Kararları, D.D.S.127

İlgili Resmi Gazeteler. 4721 Sayılı Medeni Kanun. Uzlaşma Yönetmelikleri. 213 Sayılı VUK. VUK Gerekçesi. GİB, VUK.m.ek-6 hakkındaki Özelgesi.www.gib.gov.tr. 